\title{
Spatial concentration of creative industries and location of creative clusters in Poland
}

\author{
Beata Namyślak (i) - Waldemar Spallek (i)
}

Accepted: 11 October 2021 / Published online: 24 October 2021

(C) The Author(s) 2021

\begin{abstract}
The authors compared the geographical distribution of creative clusters in Poland with the spatial distribution of LQ (Location Quotient) measuring the concentration of creative entities in a given area. The study aimed to answer the following questions: what is the spatial distribution of clustering potential for creative industries?, which municipalities are home to entities forming creative clusters?, and, above all, are creative clusters actually formed in areas offering the greatest potential in this respect? In order to find answers to the above questions, the authors carried out two sub-analyses. The first led to the conclusion that only $1.9 \%$ of municipalities in Poland offer conditions for creative specialisations, including the formation of creative clusters (LQ > 1.25). The next step involved a comparison of geographical distribution of areas with clustering potential with areas being home to actual creative clusters. The authors did not observe any relationship between the value of LQ reflecting clustering potential for creative industries and the distribution and size of active creative clusters. The correlation coefficient between LQ and the number of cluster members was positive
\end{abstract}

\footnotetext{
B. Namyślak $(\bowtie) \cdot$ W. Spallek

Institute of Geography and Regional Development, University of Wroclaw, Pl. Uniwersytecki 1,

50-137 Wrocław, Poland

e-mail: beata.namyslak@uwr.edu.pl

W. Spallek

e-mail: waldemar.spallek@uwr.edu.pl
}

but weak. It shows that creative clusters in Poland are not formed in locations offering best conditions in terms of the number of potential members. Therefore, there are other factors behind the formation of cluster structures. Nevertheless, local potential should be the main driving force because it is one of the crucial components of favourable conditions for building economic specialisation and a foundation on which proper cluster structures should be built on.

Keywords Creative industries - Creative clusters · Location quotient LQ · Poland

\section{Introduction}

High propensity for cooperation is a characteristic feature of the creative sector. This feature is owed to the structure of creative entities - quite frequently they are micro-enterprises (very often sole proprietorships) pursuing simultaneously a number of projects in cooperation with different partners. The above is conducive to establishing a more or less formalised partnerships between companies, often for the purposes of only one project. The above partnerships may also include companies from other sectors of the economy. Due to the high specialisation of their offer and, most often, their small size, these entities tend to 
build networks (Huang, 2011). This type of collaboration may give rise to a cluster.

The specificity of creative activities which are the subject of this paper is the reason why the relevant clusters are not typical. Creative activities are pursued mainly by micro-enterprises, whose innovation relies on an interdisciplinary approach, dynamic exchange of experiences, interpenetration of multiple approaches and strategies, and the creation of a kind of buzz in the so-called creative milieux. Creative industries transmit development impulses to other sectors of the economy by initiating structural changes in larger economic systems. For example, a particularly valuable source of innovation is the cooperation of creative industries with new technologies (ICT, social media) (Prince, 2010). Despite the obvious advantages, including the large creative component, these activities are sometimes perceived as unproductive. In general, it can be said that the overall conditions in which creative clusters are formed and mature are specific and different from those typical for power engineering or construction clusters.

Given the importance of the creative sector for the economy and the role of clusters in improving the competitiveness of entities, the authors sought to examine the relationship between the geographical distribution of creative activities and the formation of the relevant cluster structures in Poland. The authors compared the concentration of creative entities, expressed as Location Quotient (LQ), with the locations of the existing creative clusters. The aim of the study was to answer the following questions: (1) What is the spatial distribution of clustering potential for creative industries?, (2) Which municipalities are home to entities forming creative clusters?, and, above all, (3) Are creative clusters actually formed in areas offering the greatest potential in this respect? Therefore, is it correct to assume that an increase in the number creative entities will trigger the formation of creative clusters and consequently will become a contributing factor to building economic specialisation? A trend seemingly confirming the above assumption has been observed in Poland in recent years, whereby the need to increase the number of creative entities in creative industries often forms part of development strategies of cities and regions. The present paper aims to answer the question of whether the number of operators actually translates into the formation of cluster structures.

A distinctive feature of this study is the up-todateness of information relating to clustering in creative industries (all the more significant given that cluster structures in Poland are characterised by dynamic changes). The data on the distribution of creative industries come from the database of Poland's Central Statistical Office (GUS) and show the status in 2019, while the data concerning the distribution of individual clusters have been obtained from CAWI (Computer-Assisted Web Interview) surveys conducted in 2019 among creative cluster coordinators in Poland. A detailed analysis of cluster locations was a part of a larger study. The survey inquired about the motives behind the formation of cluster structures, about internal and external links of clusters and about their reach. The results were presented in the authors' other papers-Namyślak 2019, 2020 and Mackiewicz and Namyślak 2021.

\section{The concept of creative clusters in the literature of the subject}

According to Porter's classic definition of an industrial cluster (e.g. 1998), a cluster is geographically proximate group of interconnected companies and associated institutions (suppliers, etc.) in a particular field which compete and cooperate at the same time. The present authors focused on the spatial aspects of cluster structures, and this feature, although included in the classic definition, is now assigned various levels of significance in the literature of the subject. According to most approaches, clusters are based on the links of complementarity of entities located in close proximity, because the intensity of influence is greater if companies are concentrated (cf. Gordon \& McCann, 2000; Yu, 2020). Even the most modern forms of remote communication are not able to match direct contacts (de Berranger \& Meldrum, 2000). However, there are also other opinions. For example, according to Martin and Sunley (2003), the extent to which the success of companies and clusters depends on their location should not be overestimated, while 
den Hertog and Maltha (1999) make no reference to spatial concentration at all. ${ }^{1}$

In fact, regional policy uses two concepts: a cluster and cluster initiative (cf. Morgulis-Yakushev and Solvell, 2017). A cluster initiative is a cluster-based instrument of development policy. It is a formalised forum aimed to stimulate growth and increase cluster competitiveness. The actions taken by cluster coordinators are of great importance here. In general, cluster initiatives are meant to promote the growth of clusters so that they can gain an adequate critical mass, generate intensive interactions and achieve high levels of competitiveness and innovation. Such conceptual separation into cluster and cluster initiative is not always articulated in publications. However, some studies, including the present one, in fact concern cluster initiatives.

Clusters are also created among entities engaged in creative industries. Creative industries are intellectual property activities rooted in culture and science, offering potential for the creation of added value and jobs (Department of Culture, Media and Sport, 2013). Creative clusters are established primarily in various creative environments and between entities engaged in broadly understood artistic projects, whose activities may stimulate other sectors of the economy, such as the textile industry or tourism. Clusters may also include members responsible for commercialisation whose tasks include promotion of events/products, distribution or organisation. Sometimes clusters of this kind are formed at the interface of several spheres, such as creative activities and processing (cf. Comunian and England, 2019). Creative clusters stand out from other similar structures. They are mostly made up of small enterprises whose market situation is uncertain, whose innovations have a low technology component, and whose cooperation is less formalised than in other sectors. Also characteristic of creative industries is the buzz and its importance for the development of this segment (Banks and O'Connor, 2017; Gong and Xin, 2019; Florida, 2019; Hartley et al., 2013; Landry, 2008; O’Connor, 2015).

\footnotetext{
${ }^{1}$ In recent years, due to the multitude of approaches to clustering, there have been published new studies summarising the existing research on the cluster concept (cf. Chapain and Sagot-Duvauroux, 2018).
}

Studies on creative clusters also point out to spatial relationships. Creative clusters are mostly established in metropolitan areas. For example, according to the research by Boix et al. (2015), as many as $75 \%$ of such clusters in the European Union are established in metropolitan areas. In these areas, clusters downright overlap, sharing common space, which further enhances the positive impact of synergies (Boix et al., 2014). Also Bereitschaft (2014), Hautala and Jauhiainen (2019) or a couple of years earlier Florida et al. (2010), Heebels and van Aalst (2010) observed a shift of focus from regional clusters towards clusters in urban centres that offer a large market for creative industries as well as the presence of leading cultural institutions.

Creative clusters in Poland are discussed in the literature of the subject in several aspects. For example, Jankowska and Götz (2017) described their varying levels of internationalisation. Ratalewska (2016) identified the possibilities for the development of such clusters in Poland against the background of the European Union. On the other hand, the paper by Bialic-Davendra et al. (2016) deals with the condition and operating strategy of creative clusters in Central and Eastern Europe. Central and Eastern Europe is characteristic in the sense that, as Bontje et al. (2011) and B. Marková (2014) have also shown, creative clusters established in this part of Europe are hungry for financial assistance from operational programmes. Given the main objective of this paper, the publication by Środa-Murawska and Szymańska (2013) gains importance. The authors analysed the spatial concentration of creative sector entities in Poland using the LQ (Location Quotient) method and identifying areas which offer favourable conditions for clustering but their potential is not fully utilised. The described empirical material (although it had a slightly different subject-matter scope) provided a basis for comparisons in this paper, which will be further discussed below.

In Poland, cluster structures became popular between 2007 and 2013. In this period, upon inception, they were able to benefit from funding opportunities under Operational Programmes. Also in this period a policy was adopted which regarded clusters as a key condition for increasing competitiveness. However, after a few years, it became apparent that, apart from natural clusters relying on existing resources, artificial clusters were also created, which often, after the end of 
EU funding, suspended operations failing to develop their own independent operating mechanisms. In addition, the operational programmes implemented in 2014-2020 have proved less favourable to cluster structures.

Both of the above-described conditions have led to a decrease in the number of clusters in Poland. Currently, according to the Polish Agency for Enterprise Development, there are about 130 clusters (PARP, 2018), including a majority in the IT, power engineering, construction and medical sectors. However, the problem is that in this fairly large group there are still very few mature clusters. Therefore, in 2015, the Ministry of Economy decided to select national key clusters (NKC) which are characterised by, among others, an international value chain. The above was also connected with the implementation of the Europe 2020 strategy and the smart specialisation concept promoted by the European Commission, which involves concentrating efforts and resources on a certain number of economic priorities and specialisations. Currently (September 2020) there are 15 National Key Clusters. However, none of them is a creative cluster.

\section{Creative clusters and the location of creative entities}

Relying on the list of all cluster structures in Poland complied by the Polish Agency for Enterprise Development (PARP), the authors conducted a survey among clusters engaged in creative industries. The survey was conducted twice-in 2018 and in 2019. At that time they established that there were 17 clusters of this type (active or temporarily suspended) in Poland. For 12 of them, creative industries were the core or sole type of business. For five, creative activities were secondary (in these clusters the leading activities were printing, tourism or the IT sector) (Table 1). It is difficult to indicate a leader in this set of clusters, as most of them are in the development stage.

The clusters analysed were established between 2006 and 2015, with a majority created between 2011 and 2012. Design and advertising were their most frequently declared objects. The number of entities currently making up the studied clusters ranges from 4 to 66 and in ten cases it was systematically growing until it reached the present number. Our study also showed that of the 17 investigated creative clusters, 14 are examples of Marshallian clusters, composed of small businesses with the same or similar type of activity, rooted in local ties (Markusen, 1996). In addition, one hub-and-spoke cluster was identified, composed of a single dominant entity ('hub') with a network of smaller entities around it, as well as two institutional clusters focused around public institutions (universities).

Moreover, the study showed that the factors with a significant impact on cluster formation include first of all previous contacts between companies, desire to cooperate with other entities, as well as desire to increase the range of impact, to reinforce market position and to exchange business knowledge. The links between entities within the cluster concern mainly exchange of knowledge, joint promotion and marketing activities. Common long-term development strategies which in accordance with cluster definition are typical of cluster structures were adopted only in five cases. Only two clusters had achievements in the field of innovative solutions; these were new industrial designs and new industrial technology. The range of impact of creative clusters in Poland is usually local or regional. The largest (international) reach was observed in clusters focused on film and multimedia activities. The impact of the analysed clusters on the establishment of new entities in their environment was observed only for clusters which were active also in other areas apart from creative industries, for example in IT or tourism.

The distribution of clusters and their members is shown in Fig. 1. As expected, there is a tendency for members to be located around cluster headquarters. Of the 434 entities, 412 (almost 95\%) are located less than $50 \mathrm{~km}$ (as the crow flies) from the cluster headquarters. In addition, almost half of them (204) are in the same town as the cluster headquarters. Examples where the distance between a cluster member and cluster headquarters exceeds $100 \mathrm{~km}$ are exceptional (they concern only 9 entities). This is the case for Warsaw for instance, where there are entities belonging to three different clusters whose head offices are in distant cities such as Łódź $(120 \mathrm{~km})$, Cracow $(250 \mathrm{~km})$ and Cieszyn $(320 \mathrm{~km})$.

Another characteristic feature was the concentration of clusters in Silesia (śląskie) and partly in Lesser 
Table 1 Clusters including entities active in creative industries

\begin{tabular}{|c|c|c|c|c|}
\hline Cluster name* & $\begin{array}{l}\text { Location of the } \\
\text { cluster's } \\
\text { headquarters }\end{array}$ & Type(s) of activity & $\begin{array}{l}\text { Date of } \\
\text { establish- } \\
\text { ment }\end{array}$ & $\begin{array}{l}\text { Number } \\
\text { of } \\
\text { entities }\end{array}$ \\
\hline $\begin{array}{l}\text { Digital Entertainment Cluster (formerly European Game } \\
\text { Centre) }\end{array}$ & Kraków & Video games & 2013 & 23 \\
\hline$\frac{\text { "HubClub" Śląski Klaster ICT i Multimediów (HubClub }}{\underline{\text { Silesian ICT and Multimedia Cluster) }}}$ & Ruda Śląska & ICT, multimedia & 2013 & 18 \\
\hline$\frac{\text { Klaster Bibliotek Bialskich (Biała Podlaska Library }}{\underline{\text { Cluster) }}}$ & Biała Podlaska & Cultural activity & 2010 & 4 \\
\hline$\frac{\text { Klaster Biznesu Kultury BIZ-ART. (Culture Business }}{\underline{\text { Cluster BIZ-ART) }}}$ & Elbląg & $\begin{array}{l}\text { Design, publish-ing, } \\
\text { performing arts, } \\
\text { advertising }\end{array}$ & 2011 & 5 \\
\hline$\frac{\text { Klaster Biznesów Kreatywnych (Creative Businesses }}{\underline{\text { Cluster) }}}$ & Zabrze & $\begin{array}{l}\text { Design, fashion } \\
\text { photography, mu-sic, } \\
\text { advertising }\end{array}$ & 2012 & 37 \\
\hline$\frac{\text { Klaster Innowacyjnego Przemysłu i Mody (Innovative }}{\underline{\text { Industry and Fashion Cluster) }}}$ & Łódź & $\begin{array}{l}\text { Fashion design, media, } \\
\text { advertising }\end{array}$ & 2012 & 20 \\
\hline $\begin{array}{l}\text { Klaster Kultury i Turystyki Przemysłowej (Culture and } \\
\text { Industrial Tourism Cluster) }\end{array}$ & Zabrze & $\begin{array}{l}\text { Culture, heritage, } \\
\text { tourism }\end{array}$ & 2012 & 42 \\
\hline$\frac{\text { Klaster Poligraficzno-Reklamowy (Printing and }}{\underline{\text { Advertising Cluster) }}}$ & Leszno & Printing, advertising & 2006 & 26 \\
\hline$\frac{\text { Klaster Przemysłów Kreatywnych "MadeinŚląsk" }}{\underline{\text { (MadeinŚląsk Creative Industries Cluster) }}}$ & Gliwice & $\begin{array}{l}\text { Design, archite-cture, } \\
\text { advertising, } \\
\text { multimedia }\end{array}$ & 2013 & 43 \\
\hline $\begin{array}{l}\text { Lubuski Klaster Przedsiębiorczości i Turystyki } \\
\text { (Lubuskie Province Cluster of Entrepreneurship and } \\
\text { Tourism) }\end{array}$ & Lubrza & $\begin{array}{l}\text { Tourism, recreation, } \\
\text { culture }\end{array}$ & 2015 & 20 \\
\hline $\begin{array}{l}\text { Małopolski Klaster Turystyczny Beskid ('Beskid' } \\
\text { Tourism Cluster of Małopolskie Province) }\end{array}$ & Nawojowa & Tourism, multimedia & 2011 & 10 \\
\hline $\begin{array}{l}\text { Mazurski Klaster Turystyczny (Mazurian Tourist } \\
\text { Cluster) }\end{array}$ & Mrągowo & $\begin{array}{l}\text { Tourism, culture } \\
\text { renewable energy }\end{array}$ & 2012 & 66 \\
\hline$\underline{\text { MediaKlaster }}$ & Łódź & Film activity & 2007 & 13 \\
\hline Śląska Strefa Dizajnu (Silesian Design Zone) & Cieszyn & Design, advertising & 2011 & 37 \\
\hline $\begin{array}{l}\text { Śląski Klaster Kultury, Turystyki i Rekreacji (Silesian } \\
\text { Cluster of Culture, Tourism and Recreation) }\end{array}$ & Zabrze & Culture, tourism & 2013 & 53 \\
\hline
\end{tabular}

*clusters in which creative activities are the only or dominant form of activity are highlighted

**since its inception

Source: own study (2019)

Poland (małopolskie) provinces. The remaining clusters are distributed relatively randomly. On the one hand, cluster structures exist in large urban areas, like for example in and around Łódź or Bydgoszcz and Torun. On the other hand, they are surprisingly absent in other large metropolitan areas (Poznań or Wrocław). Creative clusters do exist in capital towns of counties or in rural municipalities (e.g. Lubrza, Nawojowa or Mrągowo). In conclusion, creative clusters in Poland operate in urban and rural centres of different sizes and ranks.

Methods

The aim of the study was to compare the distribution of creative clusters in Poland with the spatial distribution of the LQ that identifies the concentration of creative entities. The authors sought to confirm or reject the hypothesis that there exists a dependency between 

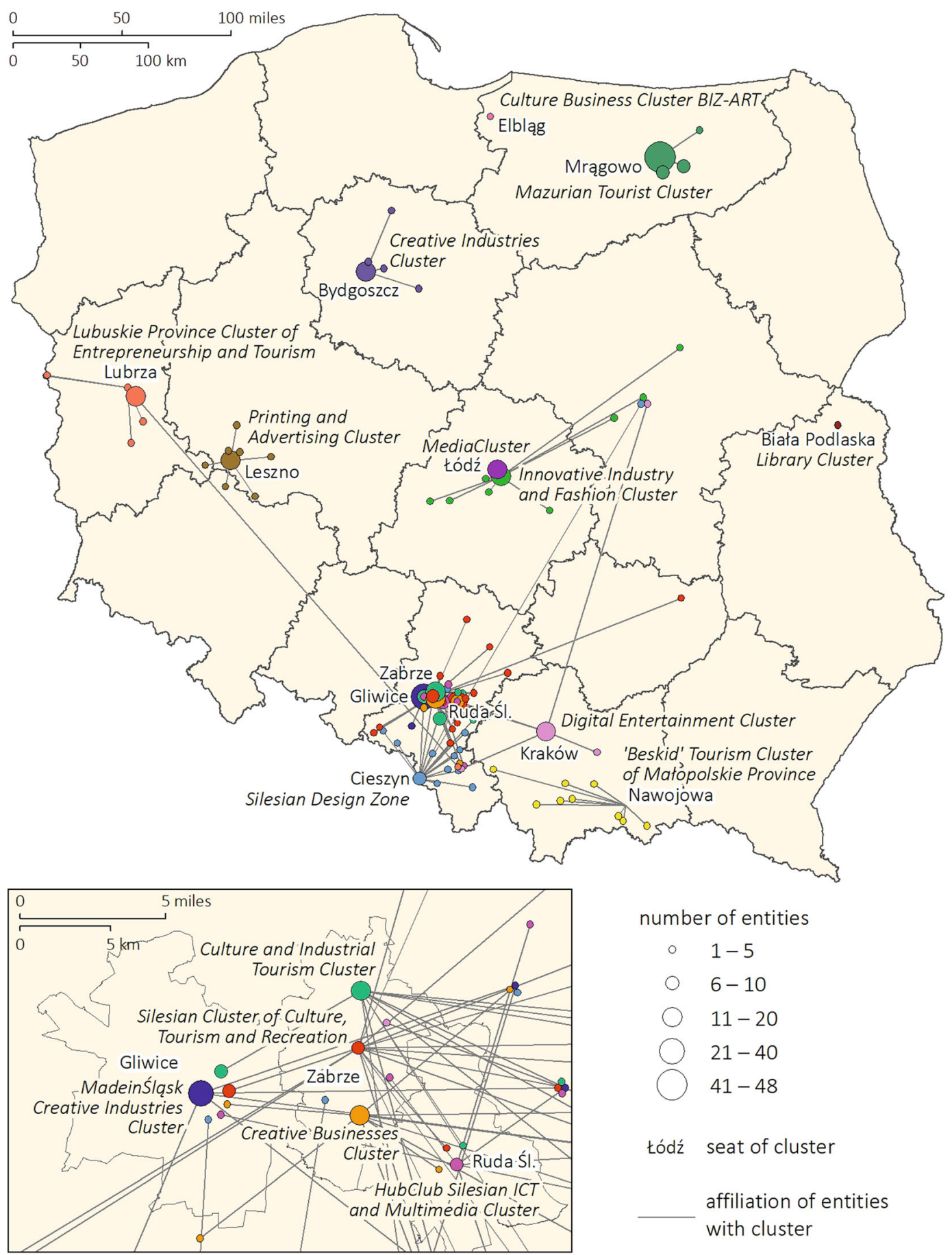

number of entities

$$
\begin{array}{ll} 
& 1-5 \\
& 6-10 \\
& 11-20 \\
& 21-40 \\
& 41-48
\end{array}
$$

\section{Łódź seat of cluster}

affiliation of entities with cluster

Fig. 1 Distribution of creative cluster members in Poland. Source: own study

clustering potential among creative activities and the number of clusters established based on such activities. A preliminary assumption was made that it could be a positive correlation of moderate strength that would show the relationship between the existing clustering potential and its utilisation.

With the previously collected data on cluster distribution already in hand, the authors proceeded 
to compute the LQ. To this end, a database was obtained from the Central Statistical Office on the number of entities engaged in creative activities. According to the British Department for Culture, Media and Sport (Department of Culture, Media and Sport, 2013) creative activities include: advertising, publishing, photography, architecture, radio and TV, film, video, music, design (among others interior design, industrial design, multimedia and fashion design), performing and visual arts, crafts, software and computer games as well as the activity of museums, galleries and libraries. Then, the list compiled as above was set against the Polish Classification of Activities. Ten classes/subclasses from three economy sectors were identified which became the subject of this study. These are: publishing activities (J.58), film and music activities (J.59), radio and television (J.60), software (J.62.01), architecture (M.71.11), advertising (M.73.1), design (M.74.1), photography (M.74.2), artistic activity (R.90), culture and heritage (R.91) (Regulation of the Council of Ministers, 2007).

In order to determine the degree of concentration of the investigated entities, the LQ values were calculated. Calculations were made for 3115 territorial units including urban municipalities, rural municipalities and urban-rural municipalities, which were divided into urban and rural areas. In particular, the above division made it possible to conduct the analysis separately for cities and rural areas.

LQ is a ratio showing the relationship between the share of the investigated sector (in this case creative activities) in the local economy and its share in the national economy. This measure allows to map increased spatial concentration of entities, which can lead to the identification of the existing potential, including latent clusters. However, it does not provide any insight into the structure of clusters or their operating mechanisms. Four variables are needed to calculate LQ:

$L Q=\frac{X_{k} / X}{Y_{k} / Y}$

where $X_{k}$-is the number of entities representing creative activities $(k)$ in the municipality; $X$-is the number of all businesses in the municipality; $Y_{k}$-is the number of entities representing creative activities (k) in Poland (= 261582$) ; Y$-is the number of all economic operators in Poland $(=4505$ 001).
The denominator value $\left(Y_{k} / Y\right)$ for all municipalities is constant and in 2019 stood at 0.0581 . The values of the location quotient indicating an economic specialisation of the municipality and the potential for clustering should exceed at least $L Q>1.25$. However, values above LQ $>1.5$ would be more desirable.

\section{Results}

When analysing the value of $L Q$, it is important to establish whether it is $L Q<1$ or $L Q>1$. In the present study, the first option was the case for the prevailing majority of units of which as many as 2931 (94\%) were assigned a LQ of less than 1 (the minimum value was 0.048 ). The above means that there is a potential shortage of creative activities that may require the provision of products or services from outside. By contrast, LQ values greater than 1 indicate a higher share of creative industries in a given municipality relative to the entire country. $L Q>1$ suggests that there is a local surplus of goods and services exceeding local demand, which may contribute to increased competitiveness of the unit. This is the case for 184 or $6 \%$ of the investigated units.

However, for the purposes of cluster research, even higher values are needed, at the level of at least $L Q>1.25$. They indicate a local specialisation and are a basis for concluding about the existence of clusters (actual or latent). This was the case for 58 $(1.9 \%)$ of the studied units and $18(0.6 \%)$ of them achieved the highest values recorded in this study (ranging from 1.5 to 1.88 ). $L Q>1.25$ was equivalent to a share of creative industry businesses of at least $7.3 \%$ of the total number of businesses in the municipality or town. It turns out that this level was hard to exceed. For $L Q>1.5$, the threshold was $8.7 \%$. This value was achieved by as few as 18 units: 11 from Masovia (mazowieckie province), 2 from Lower Silesia (dolnośląskie province), 2 from Lesser Poland (małopolskie province), 1 from Greater Poland (wielkopolskie province), 1 from Subcarpathia (podkarpackie province) and 1 from podlaskie province.

In general, the authors did not observe any relationship between the LQ value which allows to determine clustering potential for creative activities and the distribution and size of creative clusters (as clearly shown in Fig. 2). On the one hand, clusters in the metropolitan areas of Łódź, Bydgoszcz and Torun, Cracow and in Silesia (śląskie province) seem to be a 

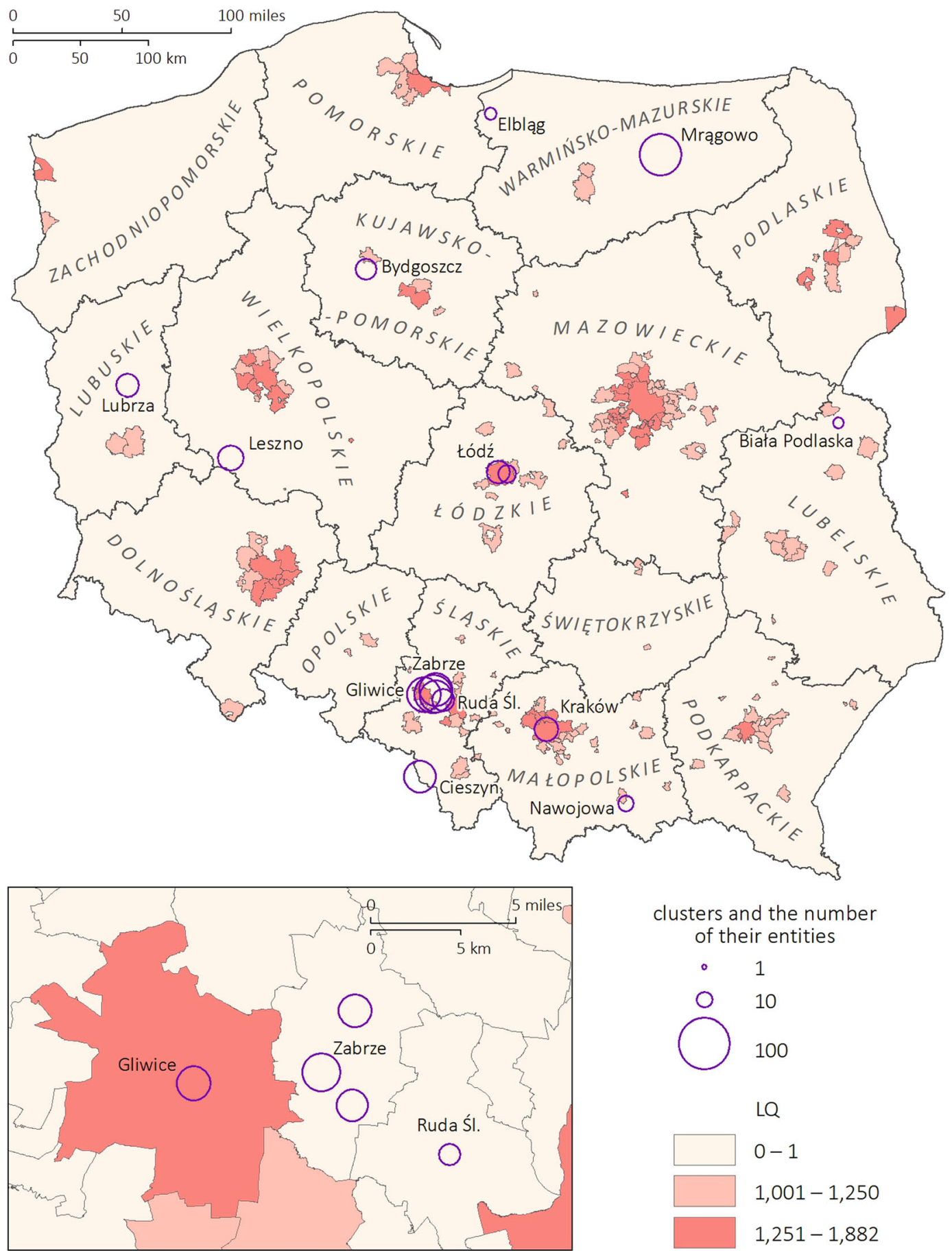

clusters and the number of their entities

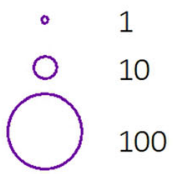

$\mathrm{LQ}$

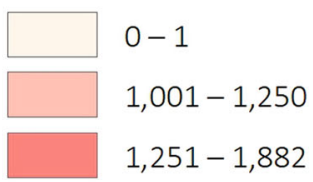

Fig. 2 Distribution of creative clusters and the LQ value for municipalities in Poland. Source: own study

confirmation of the relationship between LQ and the location of clusters. Among the above areas, Silesia has the highest concentration of creative clusters (7). On the other hand, the lack of clusters in areas with the highest concentration of creative activities (metropolitan areas of Warsaw, Wrocław, Poznań, Tri-City, Białystok and Rzeszów, and to a lesser extent also Lublin) indicates the lack of any relationship between 
LQ and the location of creative clusters. It is noteworthy that two largest clusters operate in two completely different regions. The largest cluster, with 66 members, operates in Mrągowo and its surroundings, that is in an area with a low clustering potential. The second largest, made up of 53 entities, operates in Silesia, which is an area with an evident concentration of creative activity.

Our research has shown that it is not the potential of the existing creative entities that determines the tendency for clustering, or at least that it is not the primary factor. Some significance may be attributed to the presence/proximity of a large city/urban agglomeration, but it also does not provide a full explanation. Therefore, the problem needs to be looked at from a different perspective. Other research of the author (Mackiewicz and Namyślak, 2021) suggests that regional cluster policy may be an important determinant. Support instruments offered at this level (NUTS 2) are very diversified in Poland. In many cases they are incidental rather than systemic. In the ślaskie (Silesian) province (which has the biggest number of the clusters in question) clusters are viewed as allies of local government agencies in the implementation of intraregional policy, among others relating to education support, collaboration with universities, support for regional promotion and transfer of knowledge outside the cluster structures. Silesia was also the region where creative clusters received the strongest support from the local government at the preliminary stage, during incubation of the cluster initiative and later when assistance was needed for promotion, especially in international markets. Finally, it is worth adding that in some cases the local conditions accelerated the decision to create the cluster structure. For example, the activity of cluster coordinator and such coordinator's talent for acquiring new members is important. Another important factor is the power of a major market player, whose very presence attracts new entities to the initiative, which is true especially for small and micro-enterprises.

\section{Discussion}

The LQ is a measure used in research based on spatial analyses, especially in studies relying on employment figures (e.g. Boasson and Boasson, 2011, Rosenfeld, 1998), number of enterprises (e.g. Khusaini, 2015;
Pominova et al., 2021; Wilk, 2004), agglomeration effect (among others, Tian, 2013; Yao et al., 2021), or other factors (among others, Flegg and Tohmo, 2013). Most often, authors take LQ $=1$ as a threshold above which there is a surplus vs. the reference area and below which there is a deficit. However, this interpretation is not an axiom. Depending on the intensity of the analysed phenomenon, authors adopt different threshold values. For example, Capone red. (2015) who studied tourist clusters, Crawley et al. (2012) who characterised clustering in the United Kingdom or Bergman and Feser (2020) who identified regional industrial clusters adopted $L Q>1.25$ as a threshold and this value is used most often. However, other authors adopt even higher LQ values as indicative of clustering. For example, Carroll et al. (2008), Pires et al. (2013), Suzigan et al. (2004) adopted LQ $>2$ as the minimum value indicating clustering potential. Malmberg and Maskell (2002) on the other hand adopted a LQ $>3$. Exceptionally high LQ values (4.5-5.3) were used by Yuxianga et al. (2011) in their paper about industrial clusters (including their revenues and employment) in Quingdao.

The above examples made the authors conclude that generally speaking, the degree of concentration of creative businesses at LAU2 level in Poland is not high. In the present study, the group with the highest LQ $(\mathrm{LQ}>1.25$, where the highest value of 1.882 ) represented only $1.9 \%$ of total units.

The authors also wanted to compare the conclusions of the present study with the results obtained by Środa-Murawska and Szymańska (2013) which were based on statistical data from 2010 , i.e. dating 10 years back. Importantly, the subject matter of both studies differed slightly. For example, class R91 (culture and heritage) was not taken into account in the paper by Szymańska and Środa-Murawska. It would therefore be a mistake to talk about LQ growth rate in this case. However, some cautious conclusions can be drawn regarding the similarity of the pictures obtained. It can be said with a high degree of probability that there has been a shift in the number of entities between classes. In the LQ $<1$ class, the number of municipalities went down, while in classes with LQ $>1$ this number increased, from 44 in 2010 to 184 in 2019. Thus, it can be said that, although not very rapidly, the number of creative businesses has been a growing. Additionally, a detailed analysis makes it possible to identify metropolitan areas where the number of territorial 
units with LQ $>1.25$ has increased significantly. These are mainly areas around Wrocław and Poznań, but also Białystok and to a lesser extent Łódź and Torun. On the other hand, significant drops in LQ values to below 1 can be observed around Szczecin, Olsztyn, Gorzów Wielkopolski and especially Opole, which in the study from 2010 was described as one of the areas with a higher concentration of creative businesses. In addition, a comparison of the highest LQ values in 2010 and 2019 shows that the top three places (in both studies assigned a LQ $>1.7$ ) are still occupied by the same territorial units from the capital city metropolitan area (Warsaw and the neighbouring municipalities of Piaseczno and Podkowa Leśna).

\section{Final conclusions}

The requirements for the creation and operation of creative clusters are not typical. On the one hand, this sector is distinguished by a high creative component, but on the other hand by poor adoption of high technology, less formalised cooperation and small employment. The authors have established the number of creative clusters in Poland to be 17 , with only 12 having creative activities as the only or main object. Membership of the studied clusters varies. Three of them have at least 50 members, but three other ones are small structures with no more then 10 members. In discussions conducted in the Ministry of Development and put together in the "Report on the activities of the Working Group on Cluster Policy to indicate cluster policy development directions in Poland after 2020" it was assumed that a cluster should have at least 50 members to be regarded as mature and at least 35 entities to be identified as expanding. If we used the above criteria for the analysed structures, we would have only three creative clusters in Poland meeting the number of members condition for a mature cluster and four meeting the requirement for an expanding cluster. The geographical distribution of clusters is very uneven, with Silesia and partly Lesser Poland standing out as the most active. The remaining provinces are home to up to two creative clusters. In general, the analysed clusters operate in urban and rural municipalities of different sizes and ranks. This conclusion is not in line with literature examples from other Eastern European countries. For example, using the example of Lithuania, Jurene and Jureniene (2017), or Kozina and Bole (2018) using the example of Slovenia have noticed that creative clusters are created in the largest urban centres. Similarly, Lehtonen et al. (2020), Murzyn-Kupisz and Działek (2021) and Boix et al. (2015) saw the same regularity; the latter found that as many as $75 \%$ of creative clusters in the European Union are located in metropolitan areas.

The authors also sought to establish the relationship between clustering potential in creative industries and the number of creative clusters actually formed. In order to answer the above question, the authors conducted two analyses. The first led to the conclusion that only $1.9 \%$ of municipalities in Poland have the conditions (in accordance with the interpretation of the value of LQ) for building a creative specialisation, including the establishment of creative clusters (if we adopt a stricter threshold of LQ $>1.5$ - this share goes down to $0.6 \%$ ). What is characteristic about this group is the dominance of municipalities from Masovia. In general, the spatial distribution of creative businesses in Poland is uneven. A clear concentration of creative businesses was observed in areas surrounding the largest Polish cities and especially in the highly urbanized Silesia. It is also worth noting that as compared to 2010 there can be observed a growing trend, albeit not very fast, in the number of creative businesses and the number of municipalities with LQ $>1$ has increased.

The next step was to compare the geographical diversification of clustering potential with actually formed clusters (Fig. 2). It was assumed that this comparison would indicate an existing positive correlation of moderate strength. This assumption proved to be correct only in part. The correlation coefficient between LQ and the number of entities forming a cluster was $R=0.26$. This means a positive correlation, but of weak strength. It follows that creative clusters created in Poland do not necessarily arise in places where they could find the best conditions in terms of the number of potential members. There must therefore be other factors behind the formation of cluster structures. It seems that regional cluster policy whose support instruments are very diversified may be a stronger determinant. In the Silesian province (which scored the best in the present study) creative clusters received support at various stages, among others during incubation of the cluster initiative, as well as at the stage of promotion and acquisition of new partners. Previous experience (not only of clusters in Poland) 
shows that joining a cluster alone does not trigger the mechanisms of cooperation and common value chains. Cluster members need to see real benefits in order for their rooting in the cluster to be sustainable. Therefore, what seems to be effective in this respect are relationships with local government institutions which stimulate cooperation between entities from creative industries.

It is difficult to predict the future of creative clusters or clusters in general in Poland. It must be noted that there exist conditions for the continuation or start of cluster policy at the regional level, especially in regions in which creative industries were chosen as smart specialisations, for example in the ślaskie or małopolskie provinces. In these regions, cooperation with clusters is aimed at the accomplishment of regionally important goals. Most often it takes the form of common information and promotional activities during the implementation of larger projects (e.g. educational or training projects). This paper shows that potential understood as the number of entities is not sufficient and other factors enabling cluster creation and development are required. The authors point to the dependence between the current cluster policy and the actual creative clusters; ones that are not among the National Key Clusters but are only examples of more frequently occurring smaller clusters of regional significance.

It should be noted that a large proportion of clusters still count on obtaining external funding. Much therefore depends on the decision of the European Commission and its provisions regarding the most recent budget. The previous financial perspective is not favourable for cluster structures, which has clearly weakened the role of this type of cooperation on the Polish market. Obviously, it does not apply to all clusters. Nevertheless, dependence on external funding and failure to develop own mechanisms of sustainable market operation is a significant problem of many clusters in Poland. As a result, at present some of the analysed clusters have suspended their activities. A similar situation is characteristic of Central and Eastern European countries in general. For example, Bialic-Davendra et al. (2016), Bontje et al. (2011) and Marková (2014) also observed that creative clusters established in this part of Europe strongly rely on financial assistance from operational programmes. It is important in the sense that, depending on the developments, several directions for further research in this area can be determined. If clusters continue to be used as a form of cooperation between businesses, then it will be possible to determine a model of an effective creative cluster in Poland or to assess its possible economic impact for the region. If the condition of clusters continues to deteriorate, research opportunities will be limited. For the sake of comparison, the authors would like to conduct in the future a study on the characteristics and development paths of dynamic clusters operating in Poland to take a closer look at the factors that have influenced their market position.

Funding This work was supported by the National Science Centre Poland [Narodowe Centrum Nauki w Polsce] under Grant [number 2017/25/B/HS4/00098].

\section{Declarations}

Conflict of interest The authors declares that they have no conflict of interest.

Open Access This article is licensed under a Creative Commons Attribution 4.0 International License, which permits use, sharing, adaptation, distribution and reproduction in any medium or format, as long as you give appropriate credit to the original author(s) and the source, provide a link to the Creative Commons licence, and indicate if changes were made. The images or other third party material in this article are included in the article's Creative Commons licence, unless indicated otherwise in a credit line to the material. If material is not included in the article's Creative Commons licence and your intended use is not permitted by statutory regulation or exceeds the permitted use, you will need to obtain permission directly from the copyright holder. To view a copy of this licence, visit http://creativecommons.org/licenses/by/4.0/.

\section{References}

Banks, M., \& O'Connor, J. (2017). Inside the whale (and how to get out of there): Moving on from two decades of creative industries research. European Journal of Cultural Studies, 20(6), 637-654. https://doi.org/10.1177/1367549417733 002

Bereitschaft, B. (2014). Neighbourhood change among creative-cultural districts in mid-sized US metropolitan areas, 2000-10. Regional Studies, Regional Science, 1(1), 158-183. https://doi.org/10.1080/21681376.2014.952770

Bergman, E. M. \& Feser, E. J. (2020). Industrial and regional clusters: Concepts and comparative applications, 2nd (Ed.). Web Book of Regional Science. 5. https:// researchrepository.wvu.edu/rri-web-book/5.

Bialic-Davendra, M., Bednár, P., Danko, L., \& Matošková, J. (2016). Creative clusters in Visegrad Countries: Factors conditioning cluster establishment and development. Bulletin of Geography. Socio-Economic Series, 32(32), 33-47. https://doi.org/10.1515/bog-2016-0013 
Boasson, E., \& Boasson, V. (2011). The spatial-temporal cluster development in the healthcare service industry-an integrated GIS approach. Environmental Economics, 2(3), 131-140.

Boix, R., Capone, F., De Propris, L., Lazaretti, L., \& SanchezSerra, D. (2014). Comparing creative industries in Europe. European Urban and Regional Studies, 23(4), 935-940. https://doi.org/10.1177/0969776414541135

Boix, R., Hervás-Oliver, J. L., \& De Miquel-Molina, B. (2015). Micro-geographies of creative industries clusters in Europe: From hot-spots to assemblages. Papers in Regional Science, 94(4), 753-772.

Bontje, M., Musterd, S., Kovács, Z., \& Murie, A. (2011). Pathways toward European creative-knowledge city-regions. Urban Geography, 32(1), 80-104. https://doi.org/ 10.2747/0272-3638.32.1.80

Capone, F. (Ed.). (2015). Tourist clusters, destinations and competitiveness: Theoretical issues and empirical evidences. Routledge.

Carroll, M. C., Reid, N., \& Smith, B. W. (2008). Location quotients versus spatial autocorrelation in identifying potential cluster regions. Annals of Regional Science, 42(2), 449-463.

Chapain, C., \& Sagot-Duvauroux, D. (2018). Cultural and creative clusters - a systematic literature review and a renewed research agenda. Urban Research and Practice., 13(1), 1-30. https://doi.org/10.1080/17535069.2018. 1545141

Comunian, R., \& England, L. (2019). Creative clusters and the evolution of knowledge and skills: From industrial to creative glassmaking. Geoforum, 99, 238-247. https://doi.org/ 10.1016/j.geoforum.2018.02.009

Crawley, A., Beynon, M., \& Munday, M. (2012). Making location quotients more relevant as a policy aid in regional spatial analysis. Urban Studies, 50(9), 1854-1869.

De Berranger, P., \& Meldrum, M. C. R. (2000). The development of intelligent local clusters to increase global competitiveness and local cohesion: The case of small businesses in the creative industries. Urban Studies, 37(10), 1827-1835. https://doi.org/10.1080/00420980020 080441

Den Hertog, P. \& Maltha, S. (1999). The emerging information and communication cluster in the Netherlands. In: OECD proceedings. Boosting innovation: The cluster approach. OECD, Paris, (pp. 193-218).

Department for Culture, Media and Sport (2013). Classifying and measuring the creative industries. London. https:// assets.publishing.service.gov.uk/government/uploads/ system/uploads/attachment_data/file/203296/Classifying_ and_Measuring_the_Creative_Industries_Consultation_ Paper_April_2013-final.pdf.

Flegg A. T. \& Tohmo T. (2013). Estimating regional input coefficients and multipliers: The use of the FLQ is not a Gamble. Economics Working Paper Series, 1302. University of East England, Bristol.

Florida, R. (2019). The rise of the creative class: And how it's transforming work, leisure, community, and everyday life. Basic Books.

Florida, R., Mellander, C., \& Stolarick, K. (2010). Music scenes to music clusters: The economic geography of music in the
US, 1970-2000. Environment and Planning A, 42(4), 785-804.

Gong, H., \& Xin, H. (2019). Buzz and tranquility, what matters for creativity? A case study of the online games industry in Shanghai. Geoforum, 106, 105-114. https://doi.org/10. 1016/j.geoforum.2019.08.002

Gordon, I. R., \& McCann, R. (2000). Industrial clusters: Complexes, agglomeration and/or social networks? Urban Studies, 37(3), 513-532. https://doi.org/10.1080/ 0042098002096

Hartley, J., Pottis, J., Cunningham, S., Flew, T., Keane, M., \& Banks, J. (2013). Key concepts in creative industries. SAGE Publications.

Hautala, J., \& Jauhiainen, J. S. (2019). Creativity-related mobilities of peripheral artists and scientists. GeoJournal, 84(2), 381-394. https://doi.org/10.1007/s10708-018-98663

Heebels, B., \& van Aalst, I. (2010). Creative clusters in Berlin: Entrepreneurship and the quality of place in Prenzlauer Berg and Kreuzberg. Geografiska Annaler, Series B-Human Geography, 92(4), 347-363. https://doi.org/10.1111/j. 1468-0467.2010.00357.x

Huang, Y.-H. (2011). An explanatory study of the competitive strategy of cultural and creative industries in Taiwan. European Journal of Social Sciences, 20(3), 391-400.

Jankowska, B., \& Götz, M. (2017). Internalization intensity of clusters and their impact on firm internalization: The case of Poland. European Planning Studies, 25(6), 958-977. https://doi.org/10.1080/09654313.2017.1296111

Jurene, S., \& Jureniene, V. (2017). Creative cities and clusters. Transformations and Business \& Economics, 16(2), 214-234.

Khusaini, M. (2015). A shift-share analysis on regional competitiveness - a case of Banyuwangi in District, East Java, Indonesia. Procedia-Social and Behavioral Sciences, 211, 738-744. https://doi.org/10.1016/j.sbspro.2015.11. 097

Kozina, J., \& Bole, D. (2018). The impact of territorial policies on the distribution of the creative economy: Tracking spatial patterns of innovation in Slovenia. Hungarian Geographical Bulletin, 67(3), 259-274. https://doi.org/10. 15201/hungeobull.67.3.4

Landry, C. (2008). The creative city: A toolkit for urban innovators (2nd ed.). Earthscan.

Lehtonen, M. J., Ainamo, A., \& Harviainen, J. T. (2020). The four faces of creative industries: Visualising the game industry ecosystem in Helsinki and Tokyo. Industry and Innovation, 27(9), 1062-1087. https://doi.org/10.1080/ 13662716.2019.1676704

Mackiewicz, M., \& Namyślak, B. (2021). Development conditions for creative clusters in Poland in view of institutional environment factors. Growth and Change, 52(3), 1295-1311. https://doi.org/10.1111/GROW.12503

Malmberg, A., \& Maskell, P. (2002). The elusive concept of localization economies: Towards a knowledge-based theory of spatial clustering. Environment and Planning A, 34(3), 429-449. https://doi.org/10.1068/a3457

Marková, B. (2014). Creative clusters in the Czech Republicstrategy for local development of fashionable concept? Moravian Geographical Reports, 22(1), 44-50. https://doi. org/10.2478/mgr-2014-0005 
Markusen, A. (1996). Sticky places in slippery space: A typology of industrial districts. Economic Geography, 72(3), 293-313.

Martin, R., \& Sunley, P. (2003). Deconstructing clusters: Chaotic concept or policy panacea? Journal of Economic Geography, 3(1), 5-35. https://doi.org/10.1093/jeg/3.1.5

Morgulis-Yakushev, S., \& Sölvell, Ö. (2017). Enhancing dynamism in clusters: A model for evaluating cluster organizations' bridge-building activities across cluster gaps. Competitiveness Review. an International Business Journal, 27(2), 98-112. https://doi.org/10.1108/CR-022016-001

Murzyn-Kupisz, M., \& Działek, J. (2021). Immersion in buzz or withdrawal to solitude? Artists' creative and social strategies in urban settings. City \& Community, 20(2), 160-184.

Namyślak, B. (2019). Creative clusters in Poland and theoretical cluster structures-similarities and differences. Studia Miejskie, 34, 17-40. https://doi.org/10.25167/sm.960

Namyślak, B. (2020). Barriers to the development of creative clusters in Poland. Regional Studies, Regional Science, 7(1), 412-427. https://doi.org/10.1080/21681376.2020. 1814853

O'Connor, J. (2015). Intermediaries and imaginaries in the cultural and creative industries. Regional Studies, 49(3), 374-387. https://doi.org/10.1080/00343404.2012.748982

PARP (2018). Benchmarking klastrów w Polsce-edycja 2018. Raport ogólny. (Benchmarking of clusters in Poland2018 edition. Final report). Warszawa.

Pires, J., L., Cravo, T., Lodato, S. \& Piza, C. (2013). Industrial clusters and economic performance in Brazil. IDB InterAmerican Development Bank, No IDB-WP-475.

Pominova, M., Gabe, T. \& Crawley, A. (2021). The pitfalls of using Location Quotients to identify clusters and represent industry specialization in small regions. International Finance Discussion Papers, 1329. Washington, Board of Governors of the Federal Reserve System. 2021(1329), 1-25. https://doi.org/10.17016/IFDP.2021.1329.

Porter, M. E. (1998). Clusters and the new economics of competition. Harvard Business Review, 76(6), 77-90.

Prince, R. (2010). Globalizing the creative industries concept: Travelling policy and transnational policy communities. The Journal of Arts Management, Law and Society, 40(2), 119-139. https://doi.org/10.1080/10632921.2010.486282

Ratalewska, M. (2016). The development of creative industries in Poland comparison with the European Union. In: Bilgin, M., Danis, H. (Eds.), Entrepreneurship, business and economics. Proceedings of the 15th Eurasia Business and Economics Society Conference, vol 1. Springer, (pp. 57-67).

Rozporządzenie Rady Ministrów z dnia 24 grudnia 2007 roku w sprawie Polskiej Klasyfikacji Działalności (PKD). (2007). Dz. U. nr 251, poz. 1885. (Regulation of the Council of Ministers of 24 December 2007 regarding the Polish Classification of Activities (PKD) (2007). Journal of Laws No. 251, item 1885).

Rosenfeld, S. A. (1998). Exports, competitiveness, and synergy in Appalachian industry clusters. A report to the Appalachian Regional Commission. Diane Publishing Co, Darby.

Środa-Murawska, S., \& Szymańska, D. (2013). The concentration of the creative sector firms as a potential basis for the formation of creative clusters in Poland. Bulletin of Geography. Socio-Economic Series, 20(20), 85-93. https:// doi.org/10.2478/bog-2013-0013

Suzigan, W., Furtado, J., Garcia, R., \& Sampaio, S. (2004). Clusters ou sistemas locais de produção: Mapeamento, tipologia e sugestões de políticas. Revista De Economia Política, 24(4), 96. https://doi.org/10.1590/010135172004-1606

Tian, Z. (2013). Measuring agglomeration using the standardized Location Quotient with a bootstrap method. Journal of Regional Analysis and Policy, 43(1), 186-197.

Wilk, W. (2004). The effect of changes in administrative division on the economic position of the largest cities in Poland. Miscellanea Geographica, 11, 241-247.

Yao, L., Singleton, A., Sun, P., \& Dong, G. (2021). The evolution characteristics and influence mechanism of Chinese venture capital spatial agglomeration. International Journal Environmental Research and Public Health, 18(6), 2974. https://doi.org/10.3390/ijerph18062974

$\mathrm{Yu}$, W. (2020). Creative industries agglomeration and entrepreneurship in China: Necessity or opportunity? Industry and Innovation, 27(4), 420-443. https://doi.org/10. 1080/13662716.2019.1688136

Yuxianga, Z., Xilai, Z., Chuna, L., Fengc, Y., \& Hongyu, W. (2011). The development strategy for industrial clusters in Qingdao. Energy Procedia, 5, 1355-1359.

Publisher's Note Springer Nature remains neutral with regard to jurisdictional claims in published maps and institutional affiliations. 